HARD
CHOICES 


\section{California Series on}

Social Choice and Political Economy

Edited by Brian Barry and Samuel L. Popkin 


\section{HARD CHOICES \\ How Women Decide about Work, Career, and Motherhood}

\section{KATHLEEN GERSON}


This book is a print-on-demand volume. It is manufactured using toner in place of ink. Type and images may be less sharp than the same material seen in traditionally printed University of California Press editions.

The paper used in this publication meets the minimum requirements of ANSI/NISO Z39.48-1992(R

1997)(Permanence of Paper)

University of California Press

Berkeley and Los Angeles, California

University of California Press, Ltd.

London, England

(C) 1985 by

The Regents of the University of California

Printed in the United States of America

Library of Congress Cataloging in Publication Data

Gerson, Kathleen.

Hard choices.

Bibliography: $\mathbf{p}$.

Includes index.

1. Women-United States-Social conditions.

2. Mothers-United States-Social conditions. 3. WomenEmployment-United States-History. 4. Mothers-Employment-United States-History. 5. Family size-United States-History. 6. Women-United States-Psychology. I. Title. 